\title{
Uveal Melanomların Karaciğer Metastazlarına Cerrahi Yaklașım
}

\author{
Surgical Management Of Liver Metastases From Uveal Melanoma
}

Ulaș Sözener, Tevfik Eker, Sadık Ersöz

Medicana International Ankara, Genel Cerrahi, Ankara, Türkiye

Melanomlar, melanositlerin malign neoplastik dönüșümü sonucu meydana gelir. Sıklıkla cilt kaynaklıdır fakat daha az sıklıkta göz, müköz membranlar ve santral sinir sisteminden kaynaklanabilir. Uveal melanomlar erișkinlerde en sık görülen primer intraoküler malignitelerdir. Uveal melanomlar en sık karaciğere metastaz yapar. Bu olgu sunumunda 51 yașında kadın hastanın primer koroidal melanoma sekonder gelișen karaciğer metastazına cerrahi yaklașımımız sunularak, literatür verileri eșliğinde tartıșılmıștır.

Anahtar Sözcükler: Uveal Melanom, Karaciğer Metastazı, Metastazektomi

Melanomas are malignant neoplasms of melanocytes developing predominantly in the skin but occasionally arising from eyes, mucous membranes, and the central nervous system. Uveal melanoma is the most common primary intraocular malignancy in adults. The most common site of metastasis for uveal melanoma is the liver. We report the case of a 51-year-old woman with liver metastasis from choroidal melanoma and our surgical treatment.

Key Words: Uveal Melanoma, Liver Metastases, Metastasectomy

Malign Melanomlar, melanositlerin malign dönüşümü sonucu ortaya çıkar ve cilt maligniteleri içerisinde en sik ölüm nedenidir (1). Melanositler nöral krest kaynaklı hücrelerdir ve embriyolojik gelişim sırasında göç ederek cilt dış1 organlarda da bulunur. Uveal melanomalar, cilt kaynaklı olmayan melanomalar içinde $\% 4$ oranında görülür ve erişkinde en yaygin görülen primer göz kanserleridir (2). Lezyonlar melanosit içeren iris, koroid ve silier cisim'de yerleşir. Uveanın lenfatik drenaj bulunmamasi nedeniyle metastazlar genellikle hematojen veya lokal invazyon ile olur $(3,4)$.

$\mathrm{Bu}$ yazıda koroidal melanoma sonrası karaciğer metastazı gelişen bir olgu sunulmaktadır. Klinik pratikte bu vakaların nadir görülmesi ve kuratif cerrahi girişimlerin hasta sağkalımı süresi üzerine olan anlamlı etkisi nedeniyle olgumuzu tedavi yaklaşımları ile sunarak literatür eşliğinde tartışmayı amaçladık.

\section{OLGU}

51 yaşında kadın hasta, koroidal melanoma tanis1 ve tedavisi sonrasi takipte iken yapılan tetkikler sirasinda karaciğerde kitle saptanması üzerine kliniğmize başvurdu. Özgeçmişinde, 3 yil önce koroidal melanom tanısı nedeni ile sağ göze enükleasyon uygulandığ1 öğrenildi. Fizik muayenesinde sağ göz enükle. Laboratuvar incelemelerinde hemogram ve kan biyokimyasinda patolojik değer saptanmadi. CA, alfafetoprotein ve karsinoembriyonik antijeni (CEA) düzeyleri normal idi. Abdominal ultrasonografide, karaciğer sağ lobda sınırları net seçilemeyen kitle. Dinamik karaciğer tomografisinde karaciğer boyutları normal, segment 4 lokalizasyonunda $2,8 \times 21,9 \mathrm{~mm}$ boyutunda ve segment 7'de 14,9x15mm boyutunda tümöral oluşum saptand. Her iki tümöral kitlenin de periferik kontrastlanma göstermesi nedeni ile öncelikli olarak metastatik lezyon lehine yorumlandı. Karın içi serbest sıvı ve diğer organlarda patolojik 
görünüm saptnamadi. Primer tümör odağ1 araştırması için, preop PET CT, üst ve alt gis endoskopisi yapıld. Yapılan incelemelerde karaciğgerde tariflenen lezyon dişında ek patolojiye rastlanmadi. Hasta metastatik karaciğer tümörü öntanısıyla opere edildi. Yapilan intraoperatif değerlendirmede karaciğer segmet $4 \mathrm{~b}$ ve segmet 7 'de tümöral kitle izlendi (Şekil 1). Karaciğerin diğer kısımlarında ve karın içerisinde başka tümöral kitle saptanmadi. Hastaya segment $4 \mathrm{~b}$ ve segment 7 rezeksiyonu uygulandi. Postoperatif herhangi bir komplikasyon gelişmeyen hasta 5.gün taburcu edildi. Operasyonda çıarılan piyesin histopatolojik incelemesinde her iki rezeke edilen segmentteki tümöral kitleler malign melanoma metastazı olarak raporlandi.

\section{TARTIȘMA}

Uvea cilt dışı malign melanomların en sık görüldüğü yerdir ve uveal malign melanomlar erişkinlerde en s1k görülen intraoküler malignitelerdir. Melanosit içeren iris, koroid ve silier cisimden orijinini alabilir (5).

Cilt melanomları öncelikle lenfatikler yoluyla sistemik metastaz yapma eğiliminde olmalarına rağmen, uveal traktın lenfatik drenajının olmamas1 nedeni ile uveal melanomda sistemik metastazlar genellikle hematojen yolla olmaktadir ve karaciğer en sık metastazın görüldüğü organdir $(5,6)$. Uveal melanomalarin $\% 95$ metastaz yeri karaciğer olduğundan, primer odağın tedavisi sonrasindaki takibi cilt melanomlarından farklılık göstermektedir. Uveal melanoma tanisı alan hastalar düzenli aralıklarla karaciğer metastazı açısından abdominal ultrasonografi ve gerekirse tomografi ile izlenmelidir (7).

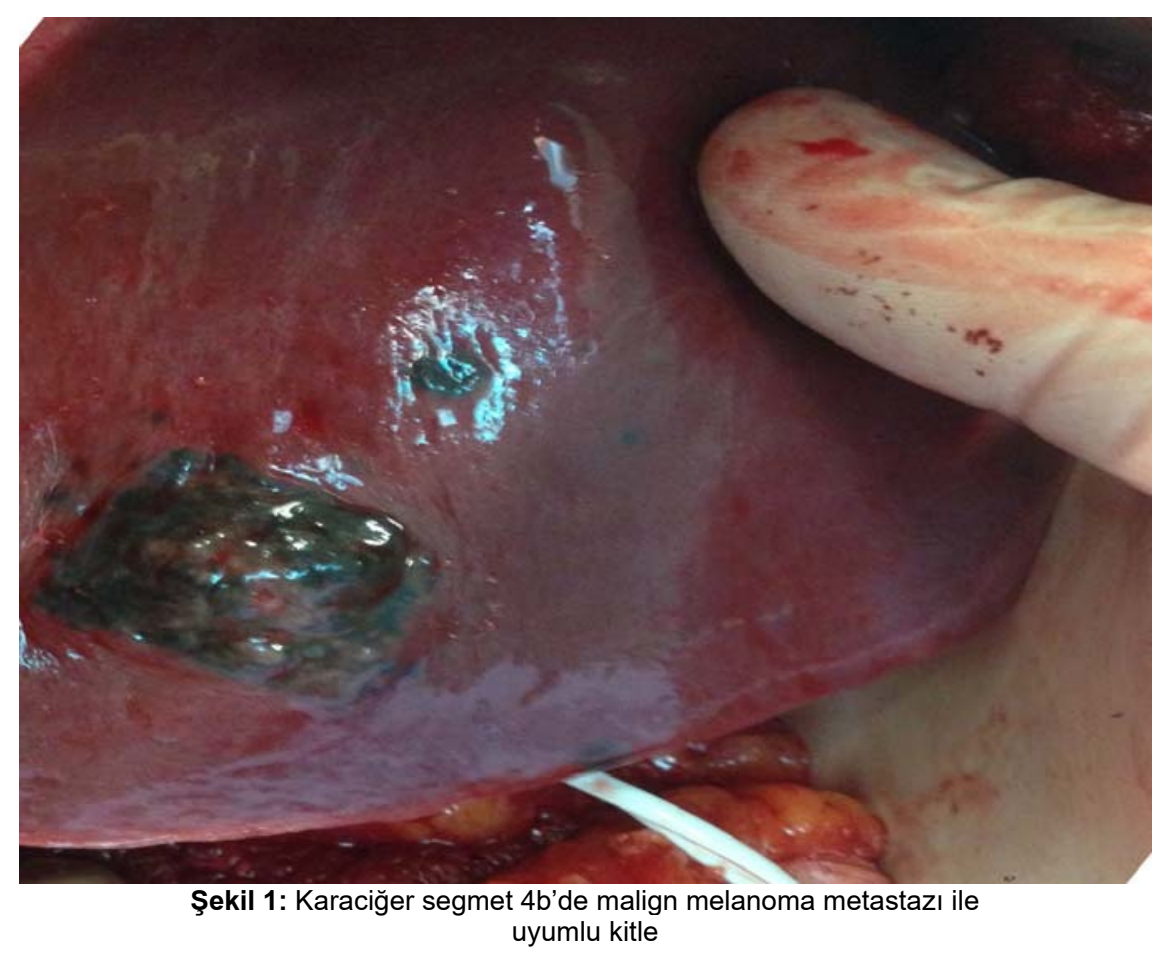

Cilt melanomlarında karaciğer metastazları sıklıkla terminal dönemde gözlenirken, uveal melanomların izole karaciğer tutulum oranı daha yüksek olduğundan küratif rezeksiyon şans1 daha yüksektir. Karaciğer metastazı uveal melanomda en önemli mortalite nedeni olmasina rağmen küratif rezeksiyon uygulanabilen hastalarda beklenen sağkalım süresi daha uzundur $(8,9,10)$. Uveal melanomların ilk tanı anında metastaz bulgusu olmamasına rağmen, 5 yil içinde olguların \%20-35'inde metastazlar ortaya çıkmaktadır $(5,6,11)$. Shields'in çalışmasında konjonktival melanom nedeniyle opere olmuş 150 vakanın incelenmesinde tümör metastazı oran1 post operatif ilk 5 ylda \%16, 10. y1lda $\% 26$ ve post operatif 15 . yilda $\% 32$ oranında meydana geldiğini saptamıştır (12). Karaciğer metastazlarının tedavisinde en etkili yön- tem metastazların rezeksiyonudur. Küratif karaciğer rezeksiyonu uygulanan olgularda kemoterapi ile birlikte yaşam beklentisi istatistiksel olarak anlamlı derecede artmaktadır (13). Karaciğer metastazlarının büyüklük veya yerleşim yerinden dolay1 rezeksiyonu mümkün değilse radyofrekans ablasyon denenebilir (14). Hepatik arteryel kemoembolizasyon, immunoembolizasyon, radyoembolizasyon, fotemustin infüzyonu veya izole hepatik perfüzyon gibi lökorejyonel tedavi yöntemleri, hasta için küratif tedavi sağlamasa da sağkalımı artırdığı çeşitli çalışmalarda gösterilmiştir (15). Biz kendi klinik uygulamamızda uveal melanoma sonrası gelişen karaciğer metastazlarında hastaların yaşam süresine anlamlı derecede katkı sağladığından dolayı küratif karaciğer rezeksiyon şansinın zorlanmasi taraftariyz. 


\section{KAYNAKLAR}

1. Girnita A, Girnita L, Stoica Z, et al. Hepatic metastases in one patient with unknown malignant melanoma. Am J Clin Oncol 1998; 21: 568-752.

2. Flaherty LE, Unger JM, Liu PY, et al. Metastatic melanoma from intraocular primary tumors: The Southwest Oncology Group experience in phase II advanced melanoma clinical trials. Am J Clin Oncol. 1998;21:568-s72.

3. Straatsma BR, Fine SL, Earle JD, et al. Enucleation versus plaque irradiation for choroidal melanoma. Ophthalmology 1988; 95: 1000-1004.

4. Günalp D, Batıoğlu F. Posterior uvea malign melanomları. Oftalmoloji 1995; 1:47-54.

5. Pyrhonen S. The treatment of metastatic uveal melanoma. Eur J Cancer 1998; 34:2730 .
6. Ma D, Gerard RD, Li XY, etal. Inhibition of metastasis of intraocular melanomas by adenovirus-mediated gene transfer of plasminogen activator inhibitor type 1 (PAI-1) in an athymic mouse model. Blood 1997; 90:2738-2746.

7. Baydar B, Özçay N, Akoğlu M. Uveal malign melanomanın karaciğer metastaz1Bir olgu sunumu. Akademik Gastroenteroloji Dergisi, 2003; 2: 152-154.

8. Rose, D., Essner, R., Hughes, H. et al. Surgical resection for metastatic melanoma to the liver.Arch Surg 136:950-955,2001.

9. Bedikian, A.Y., Legha, S.S., Mavligit, G. et al. Treatment of uveal melanoma metastatic to the liver.Cancer 1995;76:1665-1670.

10. Uzar A.I. Kolorektal dişı kanserlerin karaciğer metastazlarında cerrahi yaklaşım. Gülhane Tip Dergisi 2004;46: 360 - 365.

11. Gragoudas ES, Egan KM, Seddon JM, et al. Survival of patients with metastases from uveal melanoma. Ophthalmology 1991; 98:383-389.

12. Shields CL. Conjunctival melanoma: risk factors for recurrence, exenteration, metastasis, and death in 150 consecutive patients. Trans Am Ophthalmol Soc 2000; 98: 471 492.

13. Salmon RJ, Levy C, Plancher C, et al. Treatment of liver metastases from uveal melanoma by combined surgerychemotherapy. Eur J Surg Oncol 1998; 24:127-130.

14.Bilchik A. Radiofrequency ablation: A minimally invasive techniquewith multiple applications. Cancer. 1999; 17-21.

15. Eschelman DJ, Gonsalves CF, Sato T. Transhepatic Therapies for Metastatic Uveal Melanoma. Semin Intervent Radiol. 2013;30:39-48. 
